\title{
The Relation between Electrical Self-Stimulation Sites and Catecholamine-Containing Neurones in the Rat Mesencephalon
}

The precise neural pathways that must be stimulated to obtain the self-stimulation phenomenon have not been defined. High rates of responding are seen with electrodes implanted in the lateral hypothalamus ${ }^{1,2}$. On the basis of pharmacological experiments both STEIN $^{3}$ and PoSCHEL and NINTEMAN ${ }^{4,5}$ have proposed that the central systems involved release noradrenaline as a neurotransmitter. The present experiments investigated the relation of the self-stimulation phenomenon to structures in the mesencephalon, where large groups of catecholaminecontaining cell-bodies situated in the ventral tegmen$\operatorname{tum}^{6,7}$ give rise to ascending axons which pass through the lateral hypothalamus to be distributed to terminals in the prosencephalon.

Methods. Bipolar electrodes of tungsten wire $(100 \mu \mathrm{m}$ diameter) coated with Voltalac enamel were implanted in 72 male hooded Lister rats. 64 electrodes were implanted on a grid of sites $0.5 \mathrm{~mm}$ apart in the plane AP 4.5 of the Fifkova and MARsala ${ }^{8}$ atlas. A further 8 implantations were made in the region of the substantia nigra. At least a week after implantation each rat was subjected to 3 separate test sessions lasting $30 \mathrm{~min}$ or more in a standard operant conditioning apparatus. Attempts were made to shape the animal's behaviour towards lever pressing using monophasic $0.5 \mathrm{msec} 100 \mathrm{~Hz}$ pulses in 200 msec trains with gradually increasing current intensities. The object of this procedure was to establish which electrode sites were able to support selfstimulation behaviour at any of the current intensities tested (up to $250 \mu \mathrm{amp}$ ). The sites of the electrode tips were determined in all animals after killing under pentobarbital anaesthesia, fixation of the brains in $10 \%$ formol saline and staining by the KLÜVER-BARRERA technique ${ }^{*}$.

Results. Regular lever pressing behaviour (at rates over 500 responses $/ h$ ) was established in 21 animals, 18 of the positive electrode sites are collected together in the ventral mesencephalon (Figure) and 3 further positive sites are situated in the dorsal tegmentum in the region just lateral to the central grey matter.

Discussion. The sites from which electrical self-stimulation could be obtained appear to cluster into 2 groups a dorsal group just lateral to the central grey matter, and a ventral group situated around the interpeduncular nucleus. The latter sites correspond fairly closely to the areas A9 and A10 of DAHLSTRÖM and FUXE ${ }^{6}$, which consist of dense groups of dopamine-containing cell bodies $^{7}, 10$.
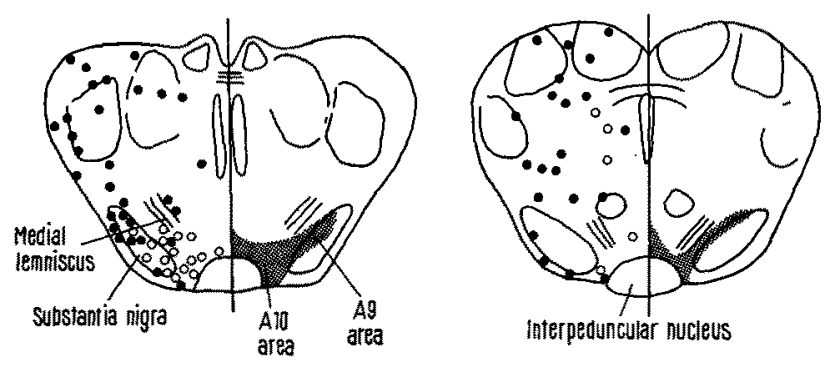

The distribution of the electrode tips plotted on the coronal planes AP 4.0 and 4.5 of the Fifkova and Marsala atlas ${ }^{8}$. Open circles indicate sites positive and filled circles sites negative for electrical self-stimulation. On the right hand side of each diagram is drawn the approximate extent of the areas $A 9$ and A10 of DAkLström and Fuxe'.
Self-stimulation behaviour is effectively inhibited by drugs of the phenothiazine and butyrophenone groups ${ }^{11,12}$ which block dopamine receptors ${ }^{13}$, and also by the tyrosine hydroxylase inhibitor $\alpha$-methyl- $p$-tyrosine ${ }^{5,14}$ although not consistently by administration of a dopamine$\beta$-oxidase inhibitor ${ }^{15}$. These findings are therefore in agreement with the possibility suggested by the above results that the central dopamine neurones originating from the ventral mesencephalic tegmentum are involved in the self-stimulation phenomenon.

The dorsal group of 3 positive sites is not associated with catecholamine-containing cell body groups. Studies with the Falck-Hillarp te: hnique have shown that some fibres originating from nor drenaline-containing cell-body groups in the lower brainstem (particularly from the locus coeruleus) may ascend in this region ${ }^{7,16}$. It therefore seems possible that the association between selfstimulation and catecholamine-containing neurones is a complex one - perhaps electrical self-stimulation can result from activation of either of 2 catecholamine systems - a ventral system of dopamine neurones and a dorsal system of noradrenaline-containing neurones ${ }^{17}$.

Résumé. 72 électrodes implantées dans les mésencéphales des rats ont été examinées pour le comportement d'autostimulation. La majorité des sites positifs entourait le noyau interpédonculaire où se situent des neurones dopaminiques.

T. J. CROW ${ }^{18}$

Departments of Physiology and Mental Health,

University of Aberdeen, Marischal College, Aberdeen AB9 1 AS (Scotland), 2 November 1970.

1 J. Ords and M. E. Olds, J. comp. Neurol. 120, 259 (1963).

2 H. A. Wilkinson and T. L. Peele, J. comp. Neurol. 121, 425 (1963).

3 L. STErn, Recent Adv. Biol. Psychiat. 4, 288 (1962).

B. P. H. Poschel and F. W. Ninteman, Life Sci. 3, 782 (1963).

5 B. P. H. Poschel and F. W. Ninteman, Life Sci. 3, 903 (1964).

B. DAhlström and K. Fuxe, Acta physiol. scand. 62 suppl. 232 (1964).

7 N. E. Anden, A. Dahlström, K. Fuxe, K. Larsson, L. Olson and U. UNGERStedT, Acta physiol. scand. 67, 313 (1966).

8 E. Fifkova and J. Marsala, in Electrophysiological Methods in Biological Research (Eds. J. BuREs, M. PeTRÁn and J. ZachaR; Academic Press, N.Y. 1967), p. 653.

${ }^{9}$ H. Klüver and E. Barrera, J. Neuropath. exp. Neurol. 12, 400 (1953).

$10 \mathrm{~K}$. FUxe, T. Hökfelt and U. UNGERstedt, in Metabolism of Amines in the Brain (Ed. G. Hooper; Macmillan, London 1969), p. 10.

11 A. Dresse, Arch, int. Pharmacodyn 159, 353 (1966).

12 P. Stark, J. A. Turk, C. E. Reoman and J. K. Henderson, J. Pharmac, exp. Ther, 166, 163 (1969).

12 N. E. Anden, A. Carlsson and J. Haggendal, A. Rev. Pharmac. $9,119(1969)$.

14 S. Gibson, E. G. McGeer and P. L. McGeER, Expl. Neurol. $27,283(1970)$.

15 S. K. Roll, Science $168,1370(1970)$.

${ }^{16} \mathrm{G}$. W. Arbuthnotr, T. J. Crow, K. Fuxe, L. Olson and U. UNGERSTEDT, Brain Res., 24, 471, (1970).

17 G. W. Arbuthnot,, T. J. Crow and P. J. Spear, J. Physiol,, Lond., 211, 28P (1970).

${ }^{18}$ Supported in part by grants from the U.K. Medical Research Council and the Mental Health Research Fund. 